\title{
THE ARIEȘENI NAPPE, OR THE MOMA AND POIANA NAPPES?
}

\author{
I. BALINTONI ${ }^{*}$ L. GHERGARI", T. BĂ BUT ${ }^{\star}$
}

\begin{abstract}
The Arieșeni Nappe was the single tectonic unit of the Biharia Nappe System involving unmetamorphosed, red Permian and metamorphosed, green Permian deposits. Deformational, microscopic and $x$-Ray diffraction studies, suggest a tectonic relationship between the two sequences. Consequently, the red Permian deposits have been attributed to the Moma Nappe, and the green Permian rocks to the Poiana Nappe. Thus, the Arieșeni Nappe disappeared. The thrust between the red Permian and the green Permian deposits realized later during the emplacement of Apusenides, due to an east-verging movement.
\end{abstract}

Keywords: Arieșeni Nappe, Permian, Alpine Metamorphism

\section{Introduction}

The Arieșeni Nappe has been separated by Bleahu, (1956). lanovici et al., (1976), and Bleahu et al., (1981), included the Arieșeni Nappe in the Codru Nappe System. Bordea et al., (1988), used for the Arieșeni Nappe the name of "MomaArieșeni Nappe". Balintoni (1994), ordered the Arieșeni Nappe in the Biharia Nappe System.

Bleahu and Dimitrescu (1964), represented it as composed from the Carboniferous greenschists, red Permian deposits and Triassic rocks. Ionescu, (1962), named the greenschists "The Arieșeni - Avram lancu Series".

Balintoni (1997), considered the Arieșeni Series as a part of the Pă iușeni Lithogroup, naming it "The Arieșeni Lithozone". Ionescu, (1962), and lanovici et al., (1976), shown that the Ariesseni Series was weakly metamorphosed in the chlorite zone of the greenschist facies.

The U/Pb isotopic data obtained by Pană (1998), on the Highis intrusions given Permian ages (264 - $267 \mathrm{Ma})$. Because these intrusions pierce a volcanosedimentary suite genetically related to them - the Pă iușeni Lithogroup results a Permian age for the Pă iușeni suite, too. Tatu (1998), studying the Highiș intrusions geochemistry, concluded that they represent a bimodal magmatism, characteristic for an extensional tectonic setting. From this reason, Balintoni (2001), considered the Pă iușeni Lithogroup a rift related volcano-sedimentary sequence.

\section{The Apuseni Mountains Permian Paradox}

The crystalline sequences from the Apuseni Mountains included by Balintoni (1997), in the Pă iușeni Lithogroup have been considered by lanovici et al., (1976), as Variscan metamorphics of Silurian - Carboniferous protolith age. These sequences were described by Savu (1962), in the Highiș-Drocea massif,

\footnotetext{
* "Babeș-Bolyai" University, 1 Kogă Iniceanu str., 3400 Cluj-Napoca, Romania
} 
as the Pă iușeni Series, and by lonescu, (1962), in the Central Bihor, as the Poiana Crișului and Ariesseni - Avram lancu Series. The above cited isotopic data (Pană 1998), completely change lanovici's et al., (1976), ideas about the "Hercynian" crystalline from the Apuseni Mountains. Thus, its protolith age becomes Permian, and consequently, its metamorphism becomes Alpine, too. Some like data were also presented by Olaru \& Dimitrescu (1994),but their confidence degree is reduced. This is because the same dating method (pallinology), gave SilurianCarboniferous ages in some older investigations (e.g. lanovici et al., 1976). As a result of these new data, from the Apuseni Mountains are known two kind of Permian sediments: red, continental, unmetamorphosed, and green, marine, metamorphosed deposits. But an amazing issue appears in the Arieșeni Nappe, where green Permian underlies red Permian. Bleahu and Dimitrescu (1964), and Bordea et al., (1988), consider these relations as being transgressive. An unpublished deformational study, realized by Balintoni and Laszlo Csontos from the Budapest University, during the summer of the 1997 along the Arieșeni cross section, shown a much more intense deformation in the Arieșeni Lithozone rocks than in the Permian rocks. Such a deformational difference was already observed by Dimitrescu et al (1965), and explained by the Variscan influence on the Arieșeni Lithozone. But, if the two sequences, the red and green deposits - are both Permian, how can be explained the deformational and metamorphic differences between them? The issue solution will be explained further.

\section{The main differences between the red and green Permian deposits}

The Arieseni cross section was revisited during the April 2002. The outcrop observation shown the followings: (a) the contact between the red and green rocks is quite clear-cut; (b) close by the contact the incompetent rocks were strong mylonitized; (c) the foliation is missing in the more competent rocks of the red Permian (sandstones and conglomerates); (d) even the coarse conglomerates of the green Permian have a foliated matrix; (e) in the red rocks cannot be detected metamorphic minerals; (f) the conglomerate pebbles of the green Permian are deformed and oriented, what is not valid for the red Permian conglomerates; $(\mathrm{g})$ the green rocks are folded at the outcrop scale, the red ones not.

In general terms, the red Permian rocks represent consolidated sediments, while the green Permian rocks represent true metamorphics. Several samples were microscopically and by the X-ray diffraction studied. The thin sections confirmed the strong mylonitization of some rock portions next to the contact (PI. II); but we do not find metamorphic minerals even in the strongest mylonitized red rocks(PI. I). On the other hand, the metamorphic minerals of the green rocks were mylonitized. Thus, the mylonitization was not a metamorphic factor and was subsequent to metamorphism. X-ray diffraction studies shown that the white mica in the red rocks is detritical 2M1 politype. In the green rocks the metamorphic $2 \mathrm{~b}$ clinochlore is abundant and the $2 \mathrm{M} 1$ white mica is strongly alterated toward the M1 type. 


\section{Discussions}

Balintoni (1994), and Balintoni et al., (1996), argumented the Apusenides origin from two different margins of the Preapulian Craton: the Codru Nappe System from its meliatic margin, and the Biharia Nappe System from its penninic margin. Among the characteristics of the two nappe systems we can moreover to add: (a) in the Codru Nappe System the Pă iușeni Lithogroup rocks are missing and the red Permian rocks abundantly develop instead of them; (b) the red Permian is only known in the Gârda and Arieșeni Nappes within the Biharia Nappe system; (c) metamorphosed Triassic rocks are also known in the Biharia Nappe System (the Vulturese-Belioara series from the Biharia Nappe), besides the Pă iușeni Lithogroup metamorphics; (d) the sole of the Baia de Aries Nappe, the highest nappe from the Biharia Nappe System, was very hot during its emplacement (Dallmeyer et al., 1994).

If we corroborate all the information exposed in the text, two inferences can be emphasized: (a) the relationship between the red and green Permian from the Arieșeni Nappe has been tectonically established; (b) if the red Permian from the Arieșeni Nappe belongs in fact to a nappe from the Codru Nappe System, then, excepting the Gârda Nappe, all the Permian deposits from the Biharia Nappe System are metamorphosed.

We suggest that the metamorphism of the Pă iușeni Lithogroup rocks was caused first of all by the hot sole of the Baia de Aries Nappe. At the beginning of the Biharides thrusting, the Baia de Aries nappe covered the entire domain occupied by the Pă iușeni Lithogroup rocks. The reaction kinetics was favored by the presence of the water in the previous marine sediments and also by the strong deformation. The hydrothermal alteration connected with the Permian magmatism can be considered, too. The Gârda Nappe rocks have been tectonically covered later and they have been insulated against the Baia de Aries heat by the Biharia Lithogroup rocks.

\section{The structure of the Arieșeni Nappe}

The Arieșeni Nappe has a special structure, not discussed but figured by Bleahu and Dimitrescu (1964), and Dimitrescu et al., (1977). Thus, red Permian not only overlies the Arieseni Lithozone but also underlies it. It is curious why the authors did not put a tectonic plane between the lower red Permian and the upper Arieșeni Lithozone, although they considered them of different ages. The Gârda Nappe has also in this area an upper subunit, the east verging Ravicești Scale. At the same time, it is important to remember that Bordea et al., (1988), added to the Ariesseni name the one of Moma. The reason for this was the resemblance of the Arieseni Nappe red Permian with the Moma Nappe Permian. Corroborating these data, we infer that the red Permian from Arieșeni Nappe does not belong to the Arieșeni Nappe, but to the Moma Nappe, the uppermost from the more important units of the Codru Nappe System. The Moma Nappe Permian probably arrived over the Arieșeni Nappe due to a subsequent thrust of little amplitude, simultaneous with the Ravicești Scale thrust. If we restore the initial locations of the Moma and Arieșeni nappes, it is easy observable that 
the green Permian of the Arieșeni nappe comes in the same structural position as the green Permian of the Poiana Nappe. Because a tectonic plane was drawn beneath the Poiana "Carboniferous conglomerates" by Rozlozsnik since 1936 , we propose the Poiana name for the second unit of the Biharia Nappe System. Thus the Arieșeni Nappe and the Arieșeni Lithozone disappear from the tectonic and lithostratigraphic nomenclature of the Biharia Nappe System.

The favored solution for the conflicting features shown by the Permian deposits from Ariesseni, strengthens the reasoning for separation of the Codru and Biharia Nappe Systems.

\section{Conclusions}

1. The Arieseni Nappe according to Bleahu and Dimitrescu (1964), and Dimitrescu et al., (1977), disappears. The red Permian deposits belong to Moma Nappe, and the red green metamorphics of the Arieșeni Lithozone are paralleled with the Poiana Lithozone of the Poiana Nappe.

2. For the priority reasons, the "Arieșeni Nappe" and the "Arieșeni Lithozone" are substituted with the "Poiana Nappe" and the "Poiana Lithozone" respectively.

3. Due to these new observations and ideas, the Biharia Nappe System will contain a single tectonic unit comprising red Permian deposits: the Gârda Nappe and its scale Ravicești.

4 The Moma Nappe becomes the second great tectonic unit of the Codru Nappe System, beside the Finis (-Ferice) Nappe.

5. The direct relationship between the unmetamorphosed and metamorphosed Permian suites disappears. In the Codru Nappe System are only found unmetamorphosed Permian deposits, while the metamorphosed Permian had as basement the Biharia Lithogroup. The main heat source for the metamorphic reactions probably was the Baia de Aries Lithogroup.

6. The Apusenides emplacement involved a late east-verging component. The results of this deformation episode were not commented before.

Acknowledgments: This paper was supported by the grant 46174/ 27.11.1997, theme 16, with World Bank.

\section{REFERENCES}

Balintoni, I., (1994a), Some new data about the Structure of the Apuseni Mountains, Romania, Studia Univ. "Babeș-Bolyai", Geologia, XXXIX, 1-2, 21-32, Cluj-Napoca.

Balintoni, I., (1994b), Structure of the Apuseni Mountains, ALCAPA II, Field Guide-Book, Rom. Jour. Tect. Reg. Geol., 75. Suppl. 2, 51 - 58, București.

Balintoni, I., (1997), Geotectonica terenurilor metamorfice din România, Ed. Carpatica, 176 p., Cluj Napoca.

Balintoni, I., (2001), Short outlook on the structure of the Apuseni Mountains. In: Bucur, I., Filipescu, S., Sasaran, E., (Eds.), Field Trip Guide, 4th Regional Meeting of IFAA, 917, Cluj University Press. 
Balintoni, I., Puște, A., Stan, R., (1996), The Codru Nappe System and the Biharia Nappe System: a comparative argumentation, Studia Univ. "Babeș-Bolyai", Geologia, XLI, 101-113, Cluj-Napoca.

Bleahu, M., (1956), Raport geologic asupra regiunii Arieșeni, Arhiva IGG.

Bleahu, M., Dimitrescu, R., (1964), Harta Geologică a României, sc. 1:100.000, foaia Arieșeni, Inst. Geol., București.

Bleahu, M., Lupu, M., Patrulius, D., Bordea, S., Ștefan, A., Panin, Ș., 1981, The structure of the Apuseni Mountains. Carp. Balk. Geol. Assoc. XII ${ }^{\text {th }}$ Congr., Giude to Excursion, B3, Inst. Geol. Geophys. Bucharest.

Bordea, S., Dimitrescu, R., Mantea, G., Stefan, A., Bordea, J., Bleahu, M., Costea, C., 1988, Harta Geologică a României, sc. 1:50.000, foaia Biharia, Inst. Geol., București.

Dallmeyer, R. D., Neubauer, F., Pană , D., Fritz, H., (1994), Variscan vs. Alpine Tecthonotermal Evolution Within the Apuseni Mountains, Romania: Evidence from $\mathrm{Ar}^{40} / \mathrm{Ar}^{39}$ Mineral Ages, ALCAPA II, Field Guide-Book, Rom. Jour. Tect. Reg. Geol., 75. Suppl. 2, 65 76, București.

Dimitrescu, R., Bleahu, M., (1966), Contribuț ii la cunoașterea stratigrafiei și structurii pânzei de Biharia, D.S. Inst. Geol., LII (1964-1965), 2, 57-66.

Dimitrescu, R., Bleahu, M., Lupu, M., (1977), Harta Geologică a României, sc. 1:50.000, foaia Avram lancu, Inst. Geol., București.

lanovici, V., Borcoș, M., Bleahu, M., Patrulius, D., Lupu, M., Dimitrescu, R., Savu, H., (1976), Geologia Munț ilor Apuseni, Ed. Acad. Rom, 631 pp, București.

Ionescu, C., (1962), Cercetă ri geologice și petrografice în cristalinul Munț ilor Bihor (Biharia), Anu. Com. Geol., XXXII, 167-209, București.

Olaru, L., Dimitrescu, R., (1994), Contributions preliminaries à la conaissance de l'âge de la série de Pă iușeni du massif cristallin Highiș, Rom. J. Stratigraphy, 76, 1-5.

Pana, D., (1998), Tectonics of the Carpathian-Pannonian region. PhD Thesis, 356 p., Univ Alberta, Edmonton, Canada.

Savu, H., (1961), Cercetă ri petrografice în cristalinul Masivului Drocea, D.S. Inst. Geol., XLIV (1956-1957), 11-34.

Tatu, M., (1998), Le Massif Highiș (Roumanie) un exemple de l'evolution du magmatisme alcalin anorogenique. These, Universite de Paris-Sud, centre d'Orsay.

\section{Plate I}

Fig. 1. Red Permian Sandstone next to contact. Microfold and deformationally oriented minerals (quartz, white mica, opaque minerals). $1 \mathrm{~N}, 40 \mathrm{x}$

Fig. 2. Red Permian sandstone next to contact. Microfold, less deformed quartz. 1N, 40x

Fig. 3. Red Permian sandstone next to contact. Strain concentration in the median zone. $1 \mathrm{~N}, 40 \mathrm{x}$

Fig. 4. Red Permian siltstone farther of contact. Oriented minerals, but weak mylonitic foliation. $1 \mathrm{~N}, 40 \mathrm{x}$

\section{Plate II}

Fig. 1. Green Permian mylonite, next to contact. Rotated rock fragments. 1N, 40x

Fig. 2. Green Permian mylonite farther of contact. Strong crushing but the rock fragment rotation is missing. $1 \mathrm{~N}, 40 \mathrm{x}$

Fig. 3. Green Permian schist far of contact. Weaker mylonitization. 1N, 40x

Fig. 4. Matrix in a green Permian metaconglomerate. Foliated but not mylonitizated. Metamorphic chlorite. $1 \mathrm{~N}, 40 \mathrm{x}$ 


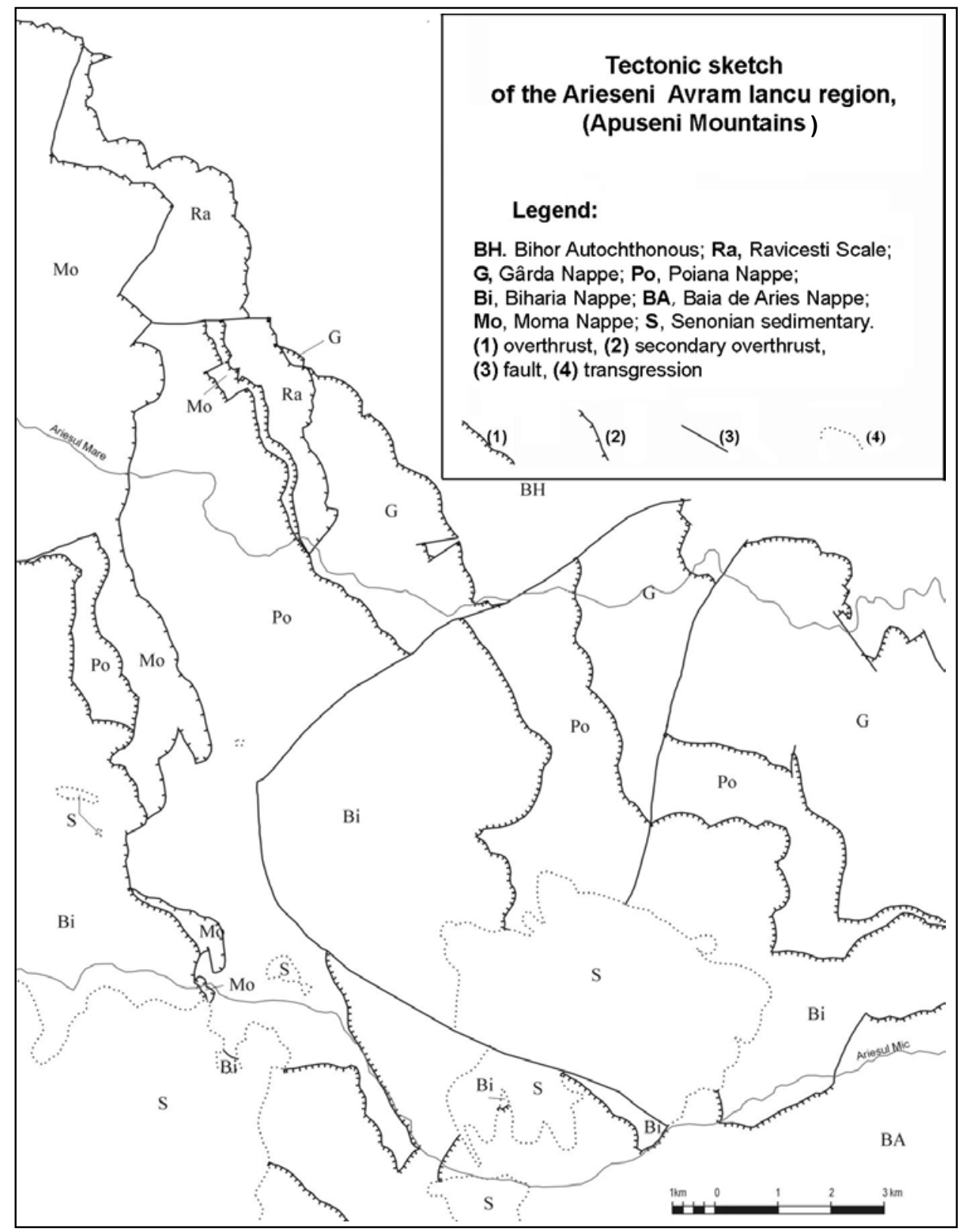


Plate I

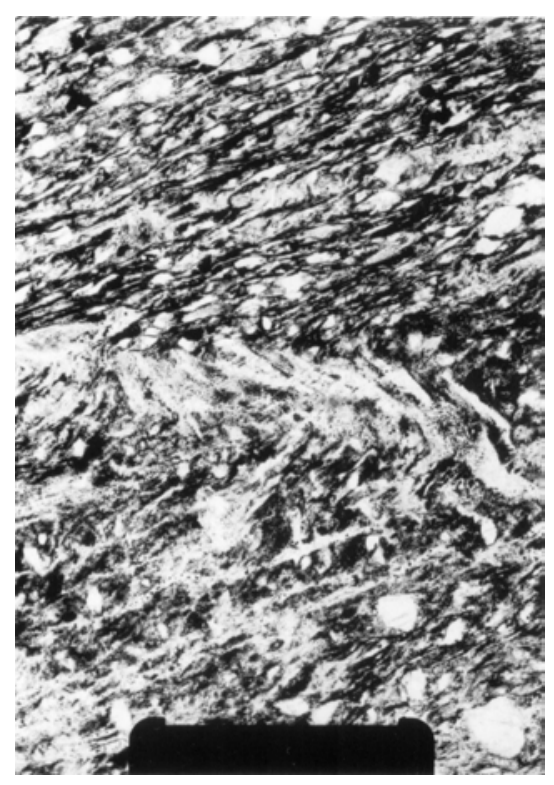

1

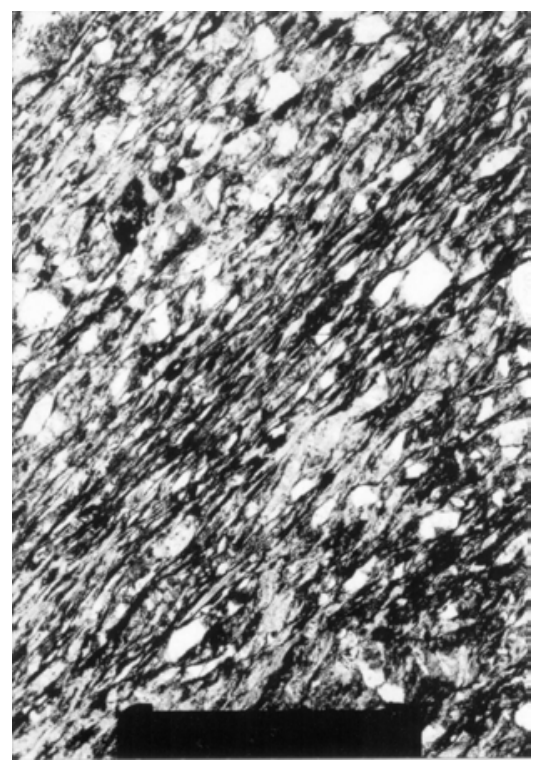

3

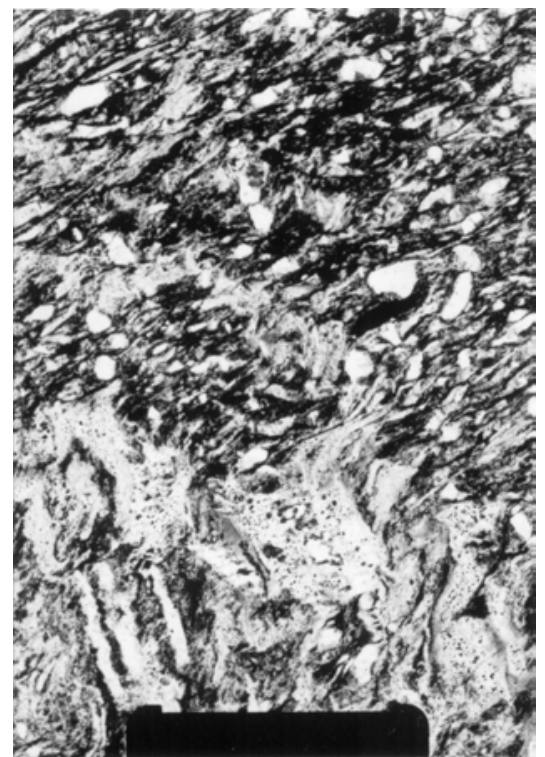

2

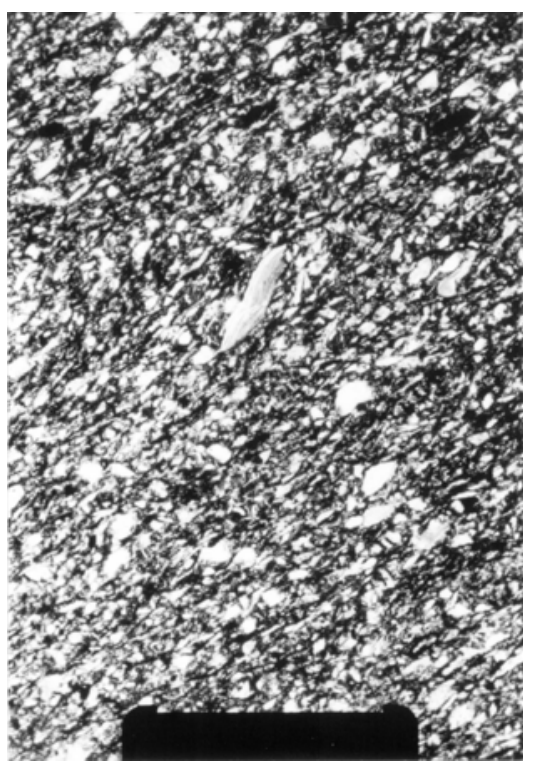

4 
I. BALINTONI, L. GHERGARI, T. BĂ BUT

Plate II

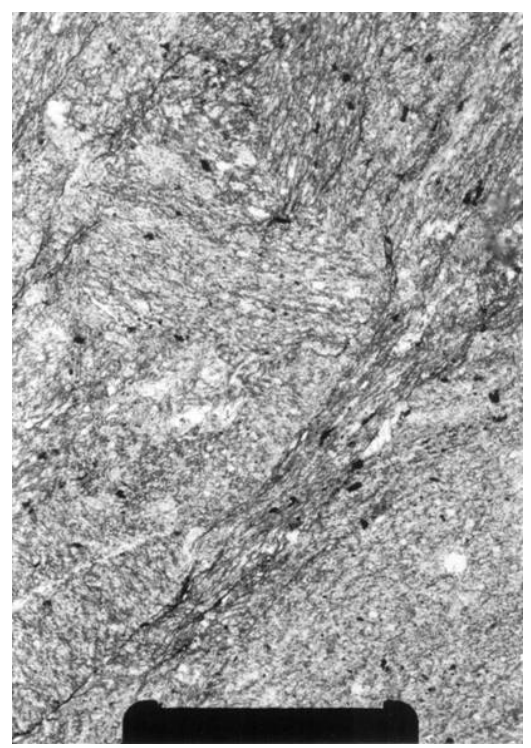

1

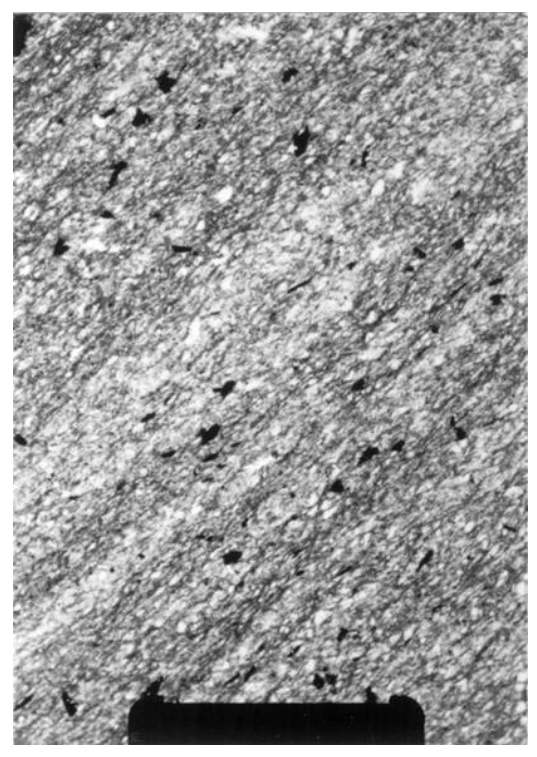

3

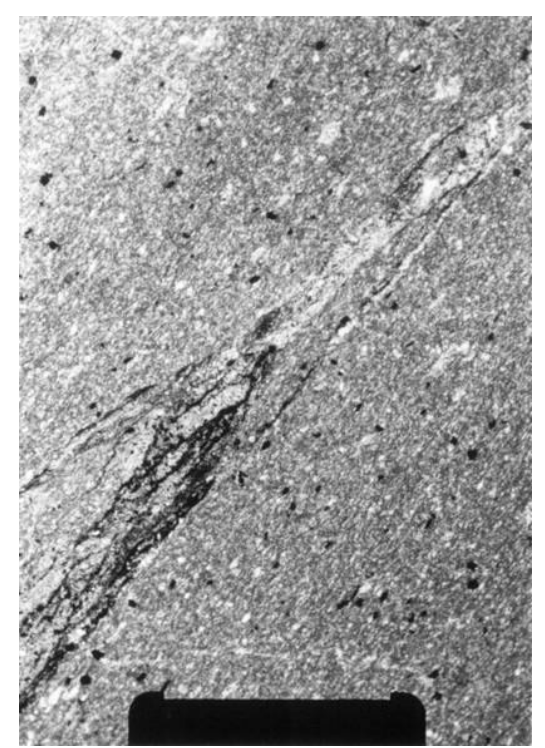

2

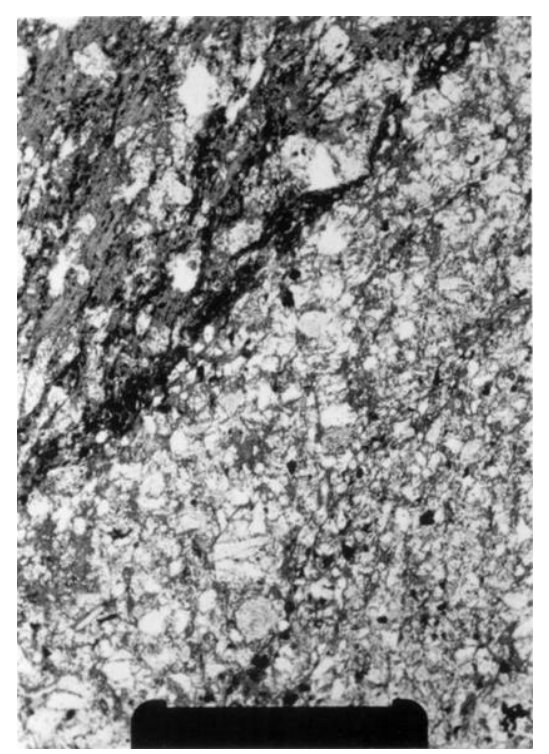

4 